\title{
PENGARUH KETEPATAN WAKTU PELAPORAN LAPORAN KEUANGAN, OPINI AUDIT, PERGANTIAN KANTOR AKUNTAN PUBLIK, PERUBAHAN REPUTASI KANTOR AKUNTAN PUBLIK, DAN INFORMASI LABA TERHADAP REAKSI INVESTOR
}

\author{
Brenda Christin Herdiana \\ Universitas Katolik Soegijapranata
}

\begin{abstract}
This research purposed to search empirical evidence danmenganalisis that this study has the effect of timeliness of financial statement reporting the reaction of investors to seek empirical evidence and analysis that this study has the effect of audit opinion, the reaction of investors to seek empirical evidence and analysis that this study has the effect of change of accounting firms publikterhadap investor reaction, to search for and analyze empirical evidence that this study has the effect of changes in accounting firm reputation publikterhadap investor reaction, to search for and analyze empirical evidence that this study has the effect of earnings information to the investor reaction.Samples were companies listed in Indonesia Stock Exchange during the years 2008-2012, obtained by purposive. The data analysis technique is a multiple linear regression analysis. Timeliness of research results is a significant effect on investor reactions, opinions no significant effect on investor reaction, switching significantly influence investors' reaction, change the reputation of KAP no significant effect on investor reaction, the EU does not significantly influence investor reaction.
\end{abstract}

Keywords : Timeliness, opinions, switching, change the reputation of the firm, the EU and the reaction of investors

\begin{abstract}
Abstrak
Penelitian ini bertujuan untuk mencari bukti empiris danmenganalisis bahwa penelitian ini memiliki pengaruh ketepatan waktu pelaporan laporan keuangan terhadap reaksi investor, untuk mencari bukti empiris dan menganalisis bahwa penelitian ini memiliki pengaruh opini audit terhadap reaksi investor, untuk mencari bukti empiris dan menganalisis bahwa penelitian ini memiliki pengaruh pergantian kantor akuntan publikterhadap reaksi investor, untuk mencari bukti empiris dan menganalisis bahwa penelitian ini memiliki pengaruh perubahan reputasi kantor akuntan publikterhadap reaksi investor, untuk mencari bukti empiris dan menganalisis bahwa penelitian ini memiliki pengaruh informasi laba terhadap reaksi investor.Sampel penelitian adalah perusahaan yang terdaftar di Bursa Efek Indonesia selama tahun 2008-2012, yang diperoleh secara purposive. Teknik analisis data adalah analisis regresi linier berganda. Hasil penelitian adalahTimelinessberpengaruh signifikan terhadap reaksi investor, opinitidak berpengaruh signifikan terhadap reaksi investor, switching berpengaruh signifikan terhadap reaksi investor, perubahan reputasi KAPtidak berpengaruh signifikan terhadap reaksi investor, UE tidak berpengaruh signifikan terhadap reaksi investor.
\end{abstract}

Kata kunci : Timeliness, opini, switching, perubahan reputasi KAP, UE dan reaksi investor 


\section{PENDAHULUAN}

Investasi merupakan hubumgan atas banyaknya dana atau sumber daya lain yang diperbuat pada masa sekarang, yang mempunyai harapan mendapatkan sejumlah keuntungan di masa depan (Eduardus, 2010:2 dalam Yanti 2012 ). Reaksi investor adalah tanggapan dari investor atau pemilik modal ketika terjadi peristiwa tertentu akan hasil saham dari sejumlah keuntungan yang diharapkannya di masa depan akan hasil investasinya (Jogiyanto, 2008). Pengujian kandungan informasi dimaksudkan untuk melihat reaksi suatu pengumuman . Jika pengumuman mengandung informasi (informasi content), maka diharapkan pasar bereaksi pada waktu pengumuman tersebut diterima oleh pasar. Esomar (2010) dalam Yanti (2012) reaksi investor dapat dilihat dari abnormal return.Bulan september 2008 adalah bulan dimana perusahaan-perusahaan terbesar di dunia ambruk. Tanggal 7 September, perusahaan prekreditan rumah Fannie Mae dan Freddie Mac, yang memberi garansi utang senilai 5,3 trilyun dolar, yang meliputi separuh lebih dari utang perkreditan rumah di AS, pun ambruk.

Nezky (2013) menyatakan bahwa sebelum krisis di tahun 2008, pertumbuhan ekonomi yang stabil menyebabkan tingkat pengangguran dan inflasi di Amerika Serikat rendah.Laporan keuangan digunakan sebagai sarana informasi bagi para pemakai laporan keuangan dan juga dipergunakan sebagai wujud pertanggungjawaban dalam indikator untuk keberlangsungan dalam pencapaian kesuksesan suatu perusahaan untuk mencapai tujuannya (Syafri, 2008).Ketepatan pelaporan laporan keuangan merupakan atribut kualitatif utama dalam laporan keuangan. ketepatwaktuan sebagai salah satu kriteria pendukung dari kerelevanan secara normatif yang harus dimiliki oleh informasi keuangan (Carslaw dan Kaplan, 1991 di dalam Sulthoni, 2013).

Ketidaktepatan waktu penyampaian laporan keuangan semacam ini dapat terjadi sebagai akibat adanya beberapa penyimpangan atau kesalahan seperti komponen dari keuangan yang kurang lengkap, keterlambatan dalam menyampaikan rencana melakukan audit atau penelaahan terbatas atas laporan keuangan internal dan salah saji yang tidak sesuai dengan Pernyataan Standar Akuntansi Keuangan (PSAK) yang mengakibatkan timbulnya reaksi dari investor berupa ketidak pastian mengenai laporan keuangan atas suatu perusahaan yang bersangkutan untuk mengambil keputusan (Fahmi, 2012:21 di dalam Diputra dan Ana, 2013).Laporan audit yang di dalamnya terdapat opini auditor adalah hasil akhir atau kesimpulan dalam proses pengumpulan dan evaluasi bukti - bukti guna menguji tindakan manajemen terhadap laporan keuangan (Messier, dkk, 2006:49 dalam Fernandes 2012).

Kantor Akuntan Publik merupakan pihak yang dapat menjadi penghubung antara pihak prinsipan dengan pihak manajer untuk mengola dan mengatur kondisi keuangan perusahaan oleh karena itu independensi auditor dalam suatu kantor akuntan publik sangat dibutuhkan agar terbebas dari suatu kecurangan, salah saji materil untuk mendiskripsikan keadaan suatu perusahaan yang sebenarnya (Fitriadi , 2011). Timbul dan berkembangnya profesi akuntan publik dipengaruhi oleh perkembangan perusahaan publik pada umumnya. Semakin banyak perusahaan publik, semakin banyak pula jasa akuntan publik yang dibutuhkan (Sumadi, 2010 dalam Firyana,2014).Terjadinya pergantian suatu kantor akuntan publik dan akuntan publik ini bermula dari suatu skandal kasus kegagalan kantor akuntan publik Arthur Andeson pada tahun 2011 yang berada di Amerika Serikat, yang tidak mampu mempertahankan independensinya terhadapnya kliennya Enron.Menurut Peraturan Menteri Keuangan Nomor: 17/PMK.01/2008 tentang Jasa Akuntan Publik mengenai pembatasan masa pemberian jasa audit oleh Kantor Akuntan Publik (KAP) selama maksimal 6 tahun buku berturut-turut dan seorang Akuntan Publik (AP) maksimal selama 3 tahun berturut-turut. 
Penggantian auditor bisa terjadi secara voluntary (sukarela) atau secara mandatory (wajib). Penggantian auditor terjadi secara voluntary dapat berasal dari sisi klien (misalnya kesulitan keuangan, manajemen yang gagal, perubahan ownership, Initial Public Offering, dan sebagainya) serta dari sisi auditor (misalnya fee audit, kualitas audit, dan sebagainya).Hasil penelitian yang telah dilakukan oleh Fitriadi (2011) mendapatkan hasil bahwa pergantian kantor akuntan publik berpengaruh terhadap reaksi investor. Namun pada penelitian yang lainnya Diputra dan Ana (2013), Fernandez (2012), tidak memiliki pengaruh terhadap reaksi investor. KAP berskala besar adalah KAP yang sudah dikenal secara mendunia dimana menyediakan jasa audit yang lebih berkualitas daripada KAP berskala kecil (Choi et al,2007). Salah satu alasan pemilihan auditor oleh manajer untuk mengaudit laporan keuangan perusahaan adalah kondisi Kantor Akuntan Publik (Diputra dan Ana, 2013). Oleh sebab itu Kantor Akuntan Publik dituntut untuk meningkatkan daya saing supaya tetap dipercaya oleh klien mereka.Hasil penelitian yang telah dilakukan oleh Fernandes (2012), Dipudra dan Ana (2013) mendapatkan hasil bawa reputasi KAP berpengaruh terhadap reaksi investor,dan penelitian sebelumnya yang dilakukan oleh Diaz (2009), Firiadi (2011) mendapatkan hasil bahwa pergantian reputasi kantor akuntan publik berpengaruh terhadap reaksi investor. Namun pada penelitian yang lainnya Riyatno (2007), tidak memiliki pengaruh terhadap reaksi investor.

\section{LANDASAN TEORI}

\section{Teori Sinyal (Signaling Theory)}

Informasi yang lengkap, akurat dan tepat waktu sangat dibutuhkan oleh investor di pasar modal untuk sarana penganalisisan suatu pengambilan keputusan investasi. Informasi yang diumumkan sebagai suatu publikasi akan memberikan sinyal atau pengaruh untuk investor dalam pengambilan keputusan investasi (Hartono, 2008 : 529 dalam Diputra dan Ana, 2013 ). Hartono (2008) juga menjelaskan beberapa pengumuman yang biasanya digunakan dalam pengujian teori ini antara lain adalah pengumuman yang berhubungan dengan laba, pengumuman deviden, pengumuman megenai pendanaan dan investasi, pengumuman yang berhubungan dengan kebijakan pemerintah, pengumuman mengenai ketenagakerjaan, pengumuman yang berhubungan dengan hukum dan kegiatan produksi, pemasaran serta penjualan, pengumuman dari manajemen dan direksi hingga pengumuman-pengumuman yangberhubungan dengan industri sekuritas.

\section{Teori Keagenan}

Teori keagenan merupakan hubungan agensi sebagai suatu kontrak di bawah satu atau lebih prinsipal yang melibatkan agen untuk melaksanakan beberapa layanan bagi mereka dengan melakukan pendelegasian wewenang pengambilan keputusan kepada agen ( Jensen dan Meckling, 1976 dalam Firyana, 2014). Adanya perbedaan informasi ini dapat menyebabkan masalah agensi .Menurut Sari dan Riduwan (2012)masalah agensi muncul akibat adanya kesenjangan antara kepentingan pemegang saham sebagai pemilik dan manajemen sebagai pengelola. Peristiwa semacam ini menyebabkan pemilik mempunyaikemauan agar dana yang ditanamkan atau diinvestasikannya mendapatkan return maksimal, sedangkan manajer memiliki keinginan untuk memperoleh intensif atas pengelolaan dana pemilik. Adanya pemisahan kepemilikan oleh pihak principal dengan pengendalian oleh agen dalam sebuah organisasi cenderung mengakibatkanmasalah keagenan di antara pihak principal dan agent (Siallagan dan Machfoedz, 2006). 


\section{Ketepat waktuan penyampaian laporan keuanagan}

Menurut SFAC No. 1 Objectives of Financial Reporting by Business Enterprises (1978)tujuan pelaporan keuangan perusahaan adalah untuk menyajikan informasi yang bermanfaat dalam proses pengambilan keputusan bisnis dan ekonomi. Statement ini merupakan turunan dari Trueblood Reportdengan beberapa judgment penilaian yang lebih berorientasi pada penggunaSehingga suatu informasi yang relevan akan berguna untuk pemakai laporan keuangan jika dalam pelaporannya tepat waktu. Kondisi demikian agar pemakai tidak kehilangan fungsi dan kesempatan untuk mengambil ataupun memperoleh keputusan yang akan di buat. Jika informasi itu tidak disampaikan dengan tepat waktu maka mengakibatkan informasi akan kehilangan atau mempunyai nilai yang berkurang dalam pengambilan suatu keputusan. Menurut UU no. 8 tahun 1995 tentang Pasar Modal yang di perbarui terakhir dengan keputusan ketua BAPEPAM nomor 346/BL/2011 dalam Cokro, 2014 bahwa perusahaan publik wajib menyampaikan laporan keuangan secara berkala kepada BAPEPAM. Pelaporan dan publikasi laporan keuangan tahunan yang diaudit dan laporan tengah tahunan yang tidak diaudit adalah bersifat wajib, sedangkan penyampaian laporan keuangan tiga bulanan bersifat sukarela. Laporan keuangann tahunan wajib disampaikan kepada BAPEPAM dan LK dan diumumkan kepada masyarakat paling lambat pada akhirran bulan ketiga setelah tanggal laporan keuangan tahunan.

\section{Opini Audit}

Opini audit menurut kamus standar akuntansi (Ardiyos, 2007) adalah laporan yang dihasilkan seorang akuntan publik terdaftar sebagai kajian dari penilaiannya atas kewajaran laporan keuangan yang disajikan perusahaan.

Jenis-Jenis Opini Audit

Mulyadi (2002) dalam Fitriadi (2011), opini audit terdiri dari lima jenis yaitu:

a. Opini Wajar Tanpa Pengecualian (Unqualified Opinion)

Adalah pendapat yang diberikan ketika audit telah dilaksanakan sesuai dengan Standar Auditing (SPAP), auditor tidak menemukan kesalahan material secara keseluruhan laporan keuangan atau tidak terdapat penyimpangan dari prinsip akuntansi yang berlaku (SAK).

b. Opini Wajar Tanpa Pengecualian dengan Paragraf Penjelasan (Modified Unqualified Opinion)

Adalah pendapat yang diberikan ketika suatu keadaan tertentu yang tidak berpengaruh langsung terhadap pendapat wajar.

c. Opini Wajar Dengan Pengecualian (Qualified Opinion)

Adalah pendapat yang diberikan ketika laporan keuangan dikatan wajar dalam hal yang material, tetapi terdapat sesuatu penyimpangan/ kurang lengkap pada pos tertentu, sehingga harus dikecualikan.

d. Opini Tidak Wajar

Adalah pendapat yang diberikan ketika laporan secara keseluruhan ini dapat terjadi apabila auditor harus memberi tambahan paragraf untuk menjelaskan ketidakwajaran atas laporan keuangan, disertai dengan dampak dari akibat ketidakwajaran tersebut, pada laporan auditnya.

e. Opini Tidak Memberikan Pendapat (Disclaimer of opinion) Adalah pendapat yang diberikan ketika ruang lingkup pemeriksaan yang dibatasi, sehingga auditor tidak melaksanakan pemeriksaan sesuai dengan standar auditing yang ditetapkan IAI. 


\section{Pergantian Kantor Akuntan Publik}

Penggantian KAP adalah penggantian yang dilakukan oleh perusahaan terhadap auditor atau Kantor Akuntan Publik yang telah mengaudit laporan keuangannya(Fiiriana, 2014).Di Indonesia, rotasi KAP bersifat mandatory dengan ditetapkannya Peraturan Menteri Keuangan.

\section{Reputasi Kantor Akuntan Publik}

Sebuah akuntan publik yang baik dan terpercaya kredibilitasnya sangat berpengaruh pada kondisi dan keadaan suatu kantor akuntan publik. Ukuranreputasi KAP dapat diukur berdasarkan jumlah klien dan prosentase dari audit fees dalam usaha mempertahankan kliennya untuk tidak berpindah pada perusahaan audit yang lain, kualitas audit yang dilakukan oleh akuntan publik dapat dilihat dari ukuran KAP yang melakukan audit ( De Angelo, 1981 dalam Fitriadi, 2011).

\section{Unexpected Earning}

UE adalah Selisih antara laba harapan (expected earnings) dan laba laporan atau aktual (reported atau actual earnings). UE atau yang disebut laba kejutan untuk merepresentasikan informasi yang belum tertangkap oleh pasar sehingga pasar akan bereaksi pada saat pengumuman (Agustina (2012).

\section{Abnormal Return}

Abnormal returnmerupakan suatu jumlah kelebihan dari sebuah return sebenarnya yang terjadi terhadap return normal yang merupakan return ekspektasi (yang diharapkan) dan merupakan return yang terjadi pada keadaan normal dimana tidak terjadi suatu peristiwa, yang dirumuskan

(Jogianto, 2009 dalam

Yanti, 2012) .

$$
R T N_{i t}=R_{i t}-E\left(R_{i t}\right)
$$

\section{Ketepatan waktu pelaporan dan reaksi Investor.}

Timelines merupakan salah satu keadaan kualitas kinerja suatu perusahaan dalam melakukan aktivitasnya dan karenanya akan menunjukan kredibilitas atau kualitas informasi.Keterlambatan pelaporan laporan keuangan dapat mempengaruhi kerelevanan sebuah informasi yang dipublikasikan sehingga mengakibatkan tingkat ketidakpastian investor dalam pengambilan keputusan ( Diputra dan Ana , 2013). Dilihat dari sudut pandangnya timelines dalam penyampaian laporan keuangan perusahaan, perusahaan yang menyampaikan laporan keuangan kepada pasar secaratepat waktu dan sesuai dengan aturan adalah perusahaan yang kinerjanya lebih baik dibanding dengan perusahaan yang terlambat dalam penyampaiannya (Cokro, 2014).Sesuai dengan teori dan penelitian terdahulu maka dikembangkan hipotesis yang pertama yaitu :

$\mathrm{H}_{1}$ :Ketepat waktuan penyampaian laporan keuangan berpengaruhterhadap reaksi investor.

\section{Pengaruh opini audit terhadap reaksi investor.}

Tugas seorang auditor adalah untuk memberikan keyakinan yang memadai bahwa laporan keuangan telah disajikan menurut standar pelaporan yang berlaku (Butar Butar, 2016). Opini audit akan diberikan oleh akuntan publik jika auditor telah melaksanakan pemeriksaaan sesuai dengan standar audit yang ditetapkan dalam SPAP dan telah mengumpulkan bahan-bahan pembuktian yang cukup untuk mendukung opini yang dinyatakannya tanpa adanya kesalahan sajian yang material pada laporan keuangan 
(Fernandes 2012).Apabila laporan keuangan tersebut disajikan secara wajar dan mendapatkan opini wajar tanpa pengecualian maka investor akan bereaksi dengan membeli saham perusahaan tersebut, tetapi apabila perusahaan mendapatkan opini qualified, opini ini dapat mempengaruhi harga saham yang dapat memberikan sinyal negatif bagi investor (Sheng dan Wang, 2006 dalam Fitriadi, 2011). Pernyataan Opini audit diharapkan akan berguna dalam pengambilan keputusan yang dilakukan oleh investor atau pihak - pihak yang berkepentingan, karena dengan berkembangnya aktivitas pasar modal yang pesat saat ini membawa perubahan yang besar pada tuntutan kualitas informasi. Apabila mengandung informasi yang bermanfaat maka diharapkan pasar akan bereaksi pada saat informasi tersebut diterima oleh pasar.(Fitriadi , 2011). Perusahaan dinyatakan dengan kondisi wajar dalam keadaan apapun yang material maka seorang auditor dapat memberikan pernyataan opini wajar tanpa pengecualian. Investor akan memberikian reaksi dengan membeli saham pada perusahaan tersebut apabila mendapatkan opini wajar tanpa pengecualian (Diputra dan Ana , 2013). Sesuai dengan teori dan penelitian terdahulu maka dikembangkan hipotesis yang kedua yaitu :

\section{$\mathrm{H}_{2}$ :Opini audit berpengaruh terhadap reaksi investor.}

\section{Pergantian kantor akuntan dan reaksi investor.}

Dengan tersedianya investasi yang akan diperbuat oleh seorang investor investor, maka terdapat aktivitas penawaran dan permintaan di bursa efek indonesia, untuk memperoleh harga keseimbangan (equilibirium price) atau yang biasa kita sebut dengan market value. Keseimbangan harga ini mencerminkan suatu aktivitas tindakan kolektif antara pembeli dan penjual yang berpedoman pada informasi yang ada. Adanaya suatu informasi baru, memperkirakan bahwa para pembeli dan penjual saham yang biasanya disebut sebagai investor segera melakukan tindakan dengan mempertimbangkan informasi yang ada sehingga tercipta suatu keseimbangan baru. Pergantian Kantor Akuntan Publik dipercaya dapat mempengaruhi perilaku harga saham di bursa akibat dari aksi investor yang menginginkan keuntungan dari kejadian tersebut (Cokro, 2014). Menurut Diputra dan Ana (2013) apabila dilakukan pergantian kantor akuntan publik memberikan kondisi dimana investor dihadapkan pada ketidakpastian yang tinggi terhadap hasil kegiatan investasinya,Akibat adanya pergantian KAP tersebut investor dihadapkan pada hal yang tidak pasti yang tinggi terhadap hasil kegiatan investasinya, pergantian Kantor Akuntan Publik yang diyakini dapat mempengaruhi dan mengubah perilaku harga saham di bursa efek ini memberikan dampak apakah pergantian kantor akuntan publik ini memberikan keuntungan bagi mereka. Pergantian kantor akuntan publik ini berarti memberikan pertanda bahwa perusahaan yang melakukan pergantian ini disinyalkan perusahaan ada masalah internal antara pihak kantor akuntan publik dengan pihak perusahaan yang mengharuskan mereka berganti kantor akuntan publik dan tidak memperpanjang untuk menggunakan kantor akuntan publik itu pada tahun selanjutnya. Ini mengidentifikasikan perusahaan yang mengganti kantor akuntan publiknya ditengah jalan atau tidak memperpanjangnya pada tahun berikutnya akan memberi reaksi negatif kepada investor karena mereka akan merasa ragu atas saham yang mereka tanamkan pada perusahaan yang bermasalah.Sesuai dengan teori dan penelitian terdahulu maka dikembangkan hipotesis yang ketiga yait :

\section{$\mathrm{H}_{3}$ :Pergantian kantor akuntan publik berpengaruh terhadap reaksi investor}

\section{Perubahan reputasi auditor dan reaksi investor.}

Kantor Akuntan Publik big-four maupun non big-four memiliki penilaian tersendiri dari investor. Kantor Akuntan Publik big-four yang memiliki reputasi baik dapat menjadi acuan untuk menyakinkan investor dalam berinvestasi, oleh karena itu dapat terjadi 
pengaruh terhadap harga saham (Fernandes, 2012). Pergantian KAP dari KAP Big Four ke KAP Non Big Four dapat mempengaruhi reaksi pasar yang negatif disekitar tanggal publikasi pada saat investor mengetahui bahwa adanya peristiwa perusahaan ingin menurunkan standard kualitas audit yang nantinya akan diberikan oleh perusahaan. Selain itu ada pula kecenderungan bahwa perusahaan seakan - akan terindikasi masalah krisis keuangan yang menyebabkan ketidakmampuan untuk membayar KAP sebelumnya dan menggantinya dengan KAP yang lebih kecil (Diaz, 2009). Kantor akuntan publik yang besar pasti mempunyai sumberdaya yang lebih baik dan sudah terpercaya sehingga saham yang mereka tanamkan berada pada perusahaan yang memang sudah terpercaya dengan terbukti dalam kualitas reputasi kantor akuntan. Sesuai dengan teori dan penelitian terdahulu maka dikembangkan hipotesis yang keempat yaitu :

\section{$\mathrm{H}_{4}$ :Perubahan reputasi kantor akuntan publik berpengaruh terhadap reaksi investor.}

\section{Informasi laba terhadap reaksi investor.}

Berdasarkan hasil pengujian yang dilakukan oleh Kianto dan Agustina (2012), secara keseluruhan diperoleh koefisien regresi laba bersih yang menunjukkan tanda negatif. Ini berarti penurunan pada laba bersih akan mendorong peningkatan pada abnormal return saham. Begitu pula sebaliknya, peningkatan dalam laba bersih akan mendorong pada penurunan pada abnormal return saham. Hal ini memicu perilaku atau reaksi investor untuk tetap menginvestasikan sahamnnya pada suatu perusahaan tertentu apa tidak karena dilihat adanya nilai laba bersih yang negatif yang menunjukan penurunan pada laba bersih yang meningkatkan abnormal return saham.investor akan tetap menanamkan sahamnya pada suatu perusahaan. Sesuai dengan teori dan penelitian terdahulu maka dikembangkan hipotesis yangkelima yaitu

\section{$\mathrm{H}_{5}$ :Informasi laba berpengaruh terhadap reaksi investor}

\section{METODE PENELITIAN}

\section{Populasi dan Sampel Penelitian}

Populasi adalah seperangkat unit yang menjadi perhatian peneliti (Butar Butar, 2007). Obyek atau subyek yang merupakan bagian dari wilayah generalisasi yang mempunyai karakteristik dan kualitas tertentu yang ditetapkan oleh peneliti untuk dipelajari dan kemudian ditarik kesimpulan. Penetapan sampel dalam penelitian ini dilakukan dengan menggunakan teknik non random sampling. Kriteria yang diharapkan oleh peneliti untuk sampel dalam penelitian ini adalah sebagai berikut :

1. Perusahaan yang terdaftar di BEI selama tahun 2008-2012.

2. Perusahaan yang melaporkan tanggal publikasi selama tahun 2008-2012

3. Anual Report yang dapat diakses pada BEI selama tahun 2008-2012.

4. Perusahaan yang mempunyai data lengkap mengenai laporan keuangan yang berhubungan dengan pengukuran variabel yang digunakan dalam penelitian ini

\section{Sumber dan Jenis Data Penelitian}

Data dalam penelitian ini menggunkan data sekunder. Data sekunder data penelitian sumber data penelitian yang dilakukan oleh peneliti yang didapatkan secara tidak langsung yaitu dengan media perantara. Data sekunder ini berupa annual reports dan laporan keuanganperusahaan yang ada di BEI pada tahun 2008-2012. Sumber data berasal dari yahoo finance (yahoofinance.com), website idx indonesia (idx.co.id), idx yang ada di Semarang dan website perusahaan. 


\section{Definisi dan Pengukuran Variabel Penelitian Variabel Independen}

Variabel independen adalah variabel yang mempengaruhi variabel dependen baik secara positif maupun secara negatif (Sulistyanto dan Susilawati, 2013). Dalam penelitian ini variabel independen yang digunakan ada 5, yakni :

1. Ketepatan waktu pelaporan laporan keuangan

2. Opini Audit

3. Pergantian Kantor Akuntan Publik

4. Perubahan Reputasi Kantor Akuntan Publik

5. Informasi Laba

\section{Variabel Dependen}

Variabel dependen adalah variabel utama sebuah penelitian yang menjadi perhatian utama peneliti (Sulistyanto dan Susilawati,2013). Dalam penelitian ini variabel dependennya adalah abnormal return.

\section{Alat Analisis Data \\ Statistik Deskriptif}

Statistik deskriptif untuk variabel-variabel yang digunakan dalam penelitian disajikan dalam tabel statistika deskriptif berupa nilai rata-rata (mean), nilai maksimum, minimum, dan nilai deviasi standar.

\section{Uji Asumsi Kelasik}

Uji asumsi klasik ini digunakan untuk menguji korelasi antara variabel serta penyimpangan dalam asumsi klasik, maka terlebih dahulu dilakukan uji asumsi klasik sebagai berikut:

\section{a. Uji Normalitas}

Pengujian ini dipergunakan untuk menguji model regresi, antara variabel dependen dan independen yang berdistribusi normal ataukah tidak (Ghozali, 2011). Model regresi yang baik adalah apabila berada dalam kondisi distribusi normal atau mendekati normal. Kurva yang menggambarkan distribusi normal adalah kurva normal yang berbentuk simetris. Dalam penelitian ini untuk menguji distribusi tersebut normal atau tidak maka di uji dengan menggunakan Kolmogorov - Smirnov of Fit Test $(K-S)$ tehadap masing- masing variabel. Apabila hasil menunjukan Kolmogrov-Smirnov menunjukkan nilai signifikan diatas 5\% maka data residual terdistribusi dengan normal. Sedangkan jika hasil KolmogrovSmirnov menunjukkan nilai signifikan dibawah 5\% maka data residual terdistribusi tidak normal (Ghozali, 2001).

\section{b. Uji Multikolonieritas}

Pengujian ini dipergunakan untuk menguji apakah model regresi dapat diketahui adanya korelasi atau hubungan antara variabel bebas (independen). Model regresi yang baik seharusnya tidak terjadi korelasi diantara variabel independen. Apabila variabel independen memiliki hubungan saling berkolerasi, maka variabel independen ini tidak ortogonal. Variabel ortogonal adalah variabel independen yang nilai korelasi antara sesama variabel independen sama dengan nol. Untuk mendeteksi ada atau tidaknya multikoloniearitas di dalam model regresi adalah dengan melilihat dari nilai tolerance dan lawannya Variance Inflation Factor (VIF). Model regresi yang terbebas dari multikolinieritas ialah yang mempunyai nilai toleransidi atas 0,1 atau VIF di bawah 10 (Ghozali, 2011). Apabila tolerance variance di bawah 0,1 atau VIF di atas 10, maka akan menyebabkan terjadinya multikolinieritas. 


\title{
c. Uji Heteroskedastisitas
}

Uji heteroskedastisitas mempunyai tujuan untuk menguji apakah dalam regresi terjadi adanya ketidaksamaan variance dari residual satu pengamatan ke pengamatan yang lainnya (Ghozali, 2011). Jika variance dari residual satu pengamatan ke pengamatan yang lain tetap, maka disebut homoskedastisitas dan jika berbeda disebut heteroskedastisitas. Model regresi yang baik adalah yang homoskedastisitas. Dalam penelitian ini, dengan menggunakan uji Glesjer sebagai pengujian atas heteroskedastisitas. Hal - hal yang diperhatikan dalam penerimaan ini dapat dilihat dari nilai signifikansinya diatas tingkat kepercayaan 5\%. Jika diatas 5\% maka tidak mengandung heteroskedastisitas.

\section{d. Uji Autokorelasi}

Uji autokorelasi dugunakan untuk pengujian apakah dalam model regresi linear terdapat adanya korelasi antara kesalahan pengguna pada periode $t$ dengan kesalahan pada periode t-1 (periode sebelumnya) (Ghozali, 2011). Apabila terjadi korelasi dapat dinamakan autokorelasi. Adanyaautokorelasi karena observasi yang terjadi secara berturut - turut sepanjang waktu berkaitan satu sama lainnya.Model regresi yang baik adalah regresi yang terbebas dari autokorelasi.Dalam penelitian ini untuk menguji autokorelasi menggunakan uji Durbin - Watson (DW) dimana hasil pengujian ditentukan brdasarkan nilai Durbin-Watson (DW).

\begin{abstract}
Alat Analisis Data
Dalam penelitian ini, alat analisis yang akan digunakan adalah analisis regresi linear berganda. Analisis regresi linear berganda dilakukan untuk mengetahui pengaruh ketepatan waktu pelaporan laporan keuangan, opini audit, pergantian kantor akuntan publik, perubahan reputasi kantor akuntan publik, dan informasi laba terhadap reaksi investor. Adapun model penghitungan regresinya adalah sebagai berikut :
\end{abstract}

$$
\begin{aligned}
& \text { ARit = a+b1Timelines }+ \text { b2Opini }+ \text { b3switching }+ \text { b4Reputasi_KAP } \\
& +\mathrm{b5} U \boldsymbol{E}+\text { eit }
\end{aligned}
$$

\section{Pengujian Hipotesis}

a) Uji Koefisien Determinasi

Koefisien determinasi $\left(\mathrm{R}^{2}\right)$ pada dasarnya adalah untuk mengukur atau menerangkan seberapa jauh kemampuan model dalam menenjelaskan variasi variabel independen (Ghozali, 2011). Nilai koefisien determinasi adalah antara nol dan satu. Nilai $\mathrm{R}^{2}$ yang kecil menjelaskan bahwa kemampuan variabel-variabel independen untuk menjelaskan variasi variabel dependen sangatlah terbatas. Nilai yang hampir mendekati satu berarti variabel-variabel independen memberikan hampir keseluruhan informasi yang dibutuhkan untuk memprediksi variabel dependen. Jika nilai adjusted $\mathrm{R}^{2}$ memiliki nilai negatif, maka nilai $\mathrm{R}^{2}$ dianggap bernilai nol.

b) Uji Signifikansi Simultan (Uji Regresi Statistik F)

Uji statistik F pada intinya dipergunakanuntuk menguji suatu pengaruh apakah semua variabel independen yang dimasukkan dengan cara bersama-sama atau simultan terhadap variabel dependen (Ghozali, 2011). Untuk mengambil keputusan uji F, Hipotesis nol (Ho) menyatakan bahwa keseluruhan variabel independen yang dimasukkan dalam model tidak ada atau memiliki pengaruh secara bersama-sama terhadap variabel dependen, sedangkan (Hi) menyatakan bahwa keseluruhan variabel independen mempunyai pengaruh secara signifikan terhadap variabel dependen. 
Dalam pengujian hipotesis ini, digunakan statistik $\mathrm{F}$ dengan menggunakan perbandingan antara $\mathrm{F}$ hitung dengan $\mathrm{F}$ tabel dengan persyaratan dalam pengambilan keputusan sebagai berikut:

- Jika F hitung $>\mathrm{F}$ tabel, maka Ha diterima $(\alpha=0,05)$

- $\quad$ Jika F hitung $<$ F tabel, maka Ho diterima $(\alpha=0,05)$

\section{c) Uji Signifikansi Parameter Individual (Uji Regresi Statistik T)}

Uji statistik $\mathrm{T}$ pada intinyanyadigunakan untuk mengetahui seberapa jauh satu variabel penjelas (independen) berpengaruh secara individual untuk menjelaskan variasi varibel dependen (Ghozali, 2011). Dalam penelitian ini menggunakan tingkat signifikan $95 \%$ atau $\alpha=5 \%$, dengan hasil :

- Jika P-Value $<5 \%$ maka Ho ditolak atau Ha diterima.

- Jika P-Value $>5 \%$ maka Ho diterima atau Ha ditolak.

\section{HASIL DAN PEMBAHASAN}

\section{Statistik Deskriptif}

Pada bagian ini akan dibahas mengenai statistik deskriptif pada penelitian ini. Dari data awal berjumlah 579 , ternyata ada cukup banyak data yang tidak normal sehingga data normalnya berjumlah 360 .

Tabel 4.1.

Descriptive Statistics

\begin{tabular}{|l|r|r|r|r|r|}
\hline & \multicolumn{1}{|c|}{$\mathrm{N}$} & \multicolumn{1}{|c|}{ Minimum } & \multicolumn{1}{c|}{ Maximum } & \multicolumn{1}{c|}{ Mean } & Std. Deviation \\
\hline AR & 360 &,- 79 &, 46 &,- 2687 &, 25580 \\
Timeliness & 360 &, 00 & 1,00 &, 3361 &, 47303 \\
Opini & 360 &, 00 & 1,00 &, 8556 &, 35203 \\
Switching & 360 &, 00 & 1,00 &, 1306 &, 33738 \\
Reputasi_KAP & 360 &, 00 & 1,00 &, 4361 &, 49659 \\
UE & 360 & $-3655,65$ & 1551,53 & $-8,8812$ & 217,49002 \\
Valid N (listwise) & 360 & & & & \\
\hline
\end{tabular}

Sumber: Data Sekunder yang Diolah (2016)

Berdasarkan pada tabel di atas dapat diketahui bahwa ternyata untuk AR memiliki nilai minimum sebesar 0,79 dan maksimum 0,46 serta nilai rata-rata sebesar $-0,2687$ serta standar deviasi 0,25580 yang artinya rata-rata perusahaan pada penelitian ini memiliki AR sebesar $26,87 \%$.Jadi investor mengalami tingkat pengembalian tidak normal yang merugi sebesar $26,87 \%$.

Untuk variabel Timeliness memiliki rata-rata sebesar 0,3361 dengan nilai minimum 0,00 dan nilai maksimum 1,00 serta standar deviasi sebesar 0,47303. Artinya perusahaan memiliki nilai rata-rata sebesar 33,61\%. Jadi perusahaan melaporkan laporan keuangan tepat waktu (sebelum 31 Maret) 33,61\% dan sisanya $66.39 \%$ tidak tepat waktu (melebihi tanggal 31 Maret).

Opini perusahaan memiliki nilai mean atau rata-rata sebesar 0,8556 dengan standar deviasi 0,35203 serta nilai minimum 0,00 dan maksimum 1,00. Artinya rata-rata opini perusahaan sampel cenderung wajar tanpa pengecualian. Sedangkan untuk variabel Switching perusahaan sampel memiliki nilai minimum sebesar 0,00 dan nilai maksimum 1,00 serta nilai rata-rata sebesar 0,1306 artinya perusahaan cenderung untuk tidak melakukan switching atau pergantian KAP.

Perubahan Reputasi KAP memiliki nilai minimum sebesar 0,00 dan nilai maksimum sebesar 1,00 serta nilai rata-rata 0,4361 yang artinya mayoritas perusahaan cenderung untuk tidak mengalami perubahan KAP. Sedangkan untuk UE memiliki rata- 
rata sebesar $-8,8812$ dengan nilai minimum -3655,65dan nilai maksimum 1551,53 serta standar deviasi sebesar 217,49002 . Jadi perusahaan reta-rata mengalami penurunan laba dibandingkan dengan tahun sebelumnya sebesar 8,8812\%.

\section{Hasil Pengujian Asumsi Klasik}

Uji asumsi klasik pada penelitian ini dilakukan dengan uji normalitas, multikolinearitas, autokorelasi dan uji heteroskedastisitas:

a. Uji Normalitas

Untuk pengujian normalitas data pada penelitian ini dilakukan dengan menggunakan uji Kolmogorov Sminov dengan hasil sebagai berikut:

Tabel 4.2. Hasil Uji Normalitas Awal

Tests of Normality

\begin{tabular}{|l|r|r|r|r|r|r|}
\hline & \multicolumn{3}{|c|}{ Kolmogorov-Smirnov } & \multicolumn{3}{c|}{ Shapiro-Wilk } \\
\cline { 2 - 7 } & Statistic & Df & \multicolumn{1}{c|}{ Sig. } & Statistic & \multicolumn{1}{c|}{ df } & \multicolumn{1}{c|}{ Sig. } \\
\hline Unstandardized Residual &, 226 & 579 &, 000 &, 545 & 579 &, 000 \\
\hline
\end{tabular}

Tabel 4.3. Hasil Uji Normalitas Akhir

Tests of Normality

\begin{tabular}{|l|r|r|r|r|r|r|}
\hline & \multicolumn{3}{|c|}{ Kolmogorov-Smirnov $^{\mathrm{a}}$} & \multicolumn{3}{c|}{ Shapiro-Wilk } \\
\cline { 2 - 7 } & Statistic & Df & \multicolumn{1}{c|}{ Sig. } & Statistic & \multicolumn{1}{c|}{ df } & \multicolumn{1}{c|}{ Sig. } \\
\hline Unstandardized Residual &, 039 & 360 &, 200 &, 987 & 360 &, 002 \\
\hline
\end{tabular}

Sumber: Data Sekunder yang Diolah (2016)

Berdasarkan pada tabel di atas dapat diketahui bahwa ternyata hasil pengujian untuk normalitas akhir dapat dilihat dari nilai Kolmogorof-Smirnov sig. sebesar 0,200 $>0,05$ dapat dikatakan bahwa data pada penelitian ini normal.

b. Uji Multikolinearitas

Adalah uji yang digunakan untuk mengetahui apakah antar variabel independen terjadi korelasi atau tidak. Untuk mengetahui ada tidaknya multikolinearitas maka dapat dilihat dari nilai VIF (Variance Inflation Factor) dan Tolerance. Jika nilai VIF < 10 dan Tolerance $>0,1$, maka dipastikan tidak terjadi multikolinearitas. Berikut ini adalah hasilnya:

Tabel 4.4. Hasil Pengujian Multikolinearitas

\begin{tabular}{|c|c|c|c|c|c|c|c|c|}
\hline \multirow{2}{*}{\multicolumn{2}{|c|}{ Model }} & \multicolumn{2}{|c|}{$\begin{array}{c}\text { Unstandardized } \\
\text { Coefficients }\end{array}$} & \multirow{2}{*}{$\begin{array}{c}\begin{array}{c}\text { Standardized } \\
\text { Coefficients }\end{array} \\
\text { Beta }\end{array}$} & \multirow[b]{2}{*}{$\mathrm{t}$} & \multirow[b]{2}{*}{ Sig. } & \multicolumn{2}{|c|}{ Collinearity Statistics } \\
\hline & & $\mathrm{B}$ & Std. Error & & & & Tolerance & VIF \\
\hline & (Constant) &,- 220 &, 036 & & $-6,146$ &, 000 & & \\
\hline & Timeliness &,- 064 &, 029 &,- 119 & $-2,226$ &, 027 &, 947 & 1,056 \\
\hline & Opini &,- 062 &, 041 &,- 086 & $-1,525$ & , 128 &, 854 & 1,171 \\
\hline & Switching &, 119 &, 040 & , 158 & 2,957 &, 003 & ,953 & 1,049 \\
\hline & Reputasi_KAP &, 027 &, 029 &, 052 & ,917 & ,360 &, 852 & 1,174 \\
\hline & UE & $4,668 \mathrm{E}-5$ &, 000 &, 040 &, 758 & ,449 &, 987 & 1,014 \\
\hline
\end{tabular}

a. Dependent Variable: AR

Berdasarkan pada tabel di atas dapat diketahui bahwa ternyata hasil pengujian untuk multikolinearitas memiliki nilai Tolerance untuk masing-masing variable independen $>0,1$ 
dan untuk nilai VIF $<10$ sehingga dapat dikatakan tidak terjadi multikolinearitas pada penelitian ini.

c. Uji Autokorelasi

Untuk mengetahui adanya autokorelasi dalam suatu model regresi dilakukan dengan uji Durbin Watson (DW) hasilnya adalah sebagai berikut:

Tabel 4.5. Hasil Pengujian Autokorelasi

\begin{tabular}{|l|c|r|r|r|r|}
\hline \multicolumn{7}{|c|}{ Model Summary } \\
\hline Model & R & R Square & $\begin{array}{c}\text { Adjusted R } \\
\text { Square }\end{array}$ & $\begin{array}{c}\text { Std. Error of } \\
\text { the Estimate }\end{array}$ & $\begin{array}{c}\text { Durbin- } \\
\text { Watson }\end{array}$ \\
\hline 1 &, $206^{\mathrm{a}}$ &, 042 &, 029 &, 25207 & 1,526 \\
\hline
\end{tabular}

Berdasarkan pada tabel di atas dapat diketahui bahwa ternyata hasil pengujian untuk autokorelasi sebesar 1,526 berada diantara 1,5 dan 2,5 artinya tidak terjadi autokorelasi pada penelitian ini.

d. Uji Heteroskedastisitas

Dalam penelitian ini untuk menguji heterokedastisitas digunakan uji Glejser. Dalam uji Glejser, nilai mutlak residual ( $|\mathrm{u}|$ ) diregresikan dengan variabel independen. Berikut ini adalah hasil pengujiannya:

Tabel 4.6. Hasil Pengujian Heteroskedastisitas

\begin{tabular}{|c|c|c|c|c|c|c|}
\hline \multirow{2}{*}{\multicolumn{2}{|c|}{ Model }} & \multicolumn{2}{|c|}{ Unstandardized Coefficients } & \multirow{2}{*}{$\begin{array}{c}\text { Standardized } \\
\text { Coefficients } \\
\text { Beta }\end{array}$} & \multirow[b]{2}{*}{$\mathrm{t}$} & \multirow[b]{2}{*}{ Sig. } \\
\hline & & $\mathrm{B}$ & Std. Error & & & \\
\hline \multirow[t]{6}{*}{1} & (Constant) & ,194 &, 020 & & 9,622 &, 000 \\
\hline & Timeliness &, 014 &, 016 &, 047 &, 857 & ,392 \\
\hline & Opini &, 017 & ,023 &, 043 &, 753 & ,452 \\
\hline & Switching &,- 007 &, 023 &,- 016 &,- 299 & ,765 \\
\hline & Reputasi_KAP &,- 014 &, 016 &,- 049 &,- 859 & ,391 \\
\hline & UE & $-3,724 \mathrm{E}-6$ &, 000 &,- 006 &,- 108 & ,914 \\
\hline
\end{tabular}

Berdasarkan pada tabel 4.6. dapat diketahui bahwa ternyata hasil pengujian heteroskedastisitas untuk masing-masing variable independen memiliki nilai signifikansi di atas 0,05 sehingga dengan demikian dapat dikatakan tidak terjadi heteroskedastisitas.

\section{Pengujian Model Fit}

Tabel 4.7. Hasil Uji Model Fit

\begin{tabular}{|ll|r|r|r|r|r|}
\hline Model & & Sum of Squares & \multicolumn{1}{|c|}{ Df } & Mean Square & F & Sig. \\
\hline 1 & Regression &, 998 & 5 &, 200 & 3,141 &, $009^{\text {b }}$ \\
& Residual & 22,493 & 354 &, 064 & & \\
& Total & 23,491 & 359 & & & \\
\hline
\end{tabular}


Dari tabel diatas diketahui bahwa nilai sig. F $0.009<0.05$ maka dapat dikatakan bahwa model fit jadi variabel independen dapat digunakan untuk memprediksi dependen.

\section{Pengujian Koefisien Determinasi}

Tabel 4.8. Hasil Uji Koefisien Determinasi

\begin{tabular}{|l|r|r|r|r|r|}
\hline \multicolumn{7}{|c|}{ Model Summary $^{\mathbf{b}}$} \\
\hline Model & $\mathrm{R}$ & R Square & $\begin{array}{c}\text { Adjusted R } \\
\text { Square }\end{array}$ & $\begin{array}{c}\text { Std. Error of the } \\
\text { Estimate }\end{array}$ & Durbin-Watson \\
\hline 1 &, $206^{\mathrm{a}}$ &, 042 &, 029 &, 25207 & 1,526 \\
\hline
\end{tabular}

Dari tabel diatas diketahui bahwa nilai Adjusted R Square sebesar 0.029 artinya variabel independen mempengaruhi dependen sebesar $2.9 \%$ sedangkan sisanya sebesar $97.1 \%$ dipengaruhi oleh variabel lainnya.

\section{Pengujian Hipotesis dan Pembahasan}

Setelah semua asumsi terpenuhi, maka berikutnya adalah melakukan pengujian hipotesis untuk mengetahui pengaruh variabel independen terhadap variabel dependen (reaksi investor). Pengujian dilakukan dengan menggunakan uji t dengan hasil sebagai berikut:

Tabel 4.9. Hasil Uji t

Coefficients $^{\mathrm{a}}$

\begin{tabular}{|ll|r|r|r|r|r|}
\hline \multirow{2}{*}{ Model } & \multicolumn{2}{|c|}{$\begin{array}{c}\text { Standardized } \\
\text { Unstandardized Coefficients }\end{array}$} & \multicolumn{1}{c|}{} \\
\cline { 3 - 4 } & & \multicolumn{1}{c|}{$\mathrm{B}$} & \multicolumn{1}{c|}{ Std. Error } & \multicolumn{1}{c|}{ Beta } & \multicolumn{1}{c|}{$\mathrm{t}$} & \multicolumn{1}{c|}{ Sig. } \\
\hline 1 & (Constant) &,- 220 &, 036 & & $-6,146$ &, 000 \\
& Timeliness &,- 064 &, 029 &,- 119 & $-2,226$ &, 027 \\
& Opini &,- 062 &, 041 &,- 086 & $-1,525$ &, 128 \\
& Switching &, 119 &, 040 &, 158 & 2,957 &, 003 \\
& Reputasi_KAP &, 027 &, 029 &, 052 &, 917 &, 360 \\
& UE & $4,668 \mathrm{E}-5$ &, 000 &, 040 &, 758 &, 449 \\
\hline
\end{tabular}

a. Dependent Variable: AR

Berdasarkan pada hasil pengujian hipotesis diketahui bahwa nilai signifikansi t untuk variabel Timeliness adalah sebesar $0,027<0,05$ sehingga artinya hipotesis pertama pertama yang memprediksi ketepatwaktuan penyampaian laporan keuangan berpengaruhterhadap reaksi investor pada penelitian ini diterima. Jadi terdapat pengaruh yang signifikan antara Timeliness terhadap AR (reaksi investor).

Berdasarkan pada hasil pengujian hipotesis diketahui ternyata nilai signifikansi $t$ untuk variabel Opini adalah lebih besar daripada 0,05 sehingga artinya hipotesis kedua yang memprediksi opini audit berpengaruh terhadap reaksi investor pada penelitian ini ditolak. Jadi Opini tidak berpengaruhsignifikan terhadap AR (reaksi investor). 
Berdasarkan pada hasil pengujian hipotesis ketiga diketahui bahwa nilai signifikansi $\mathrm{t}$ untuk variabel Switching lebih kecil daripada 0,05 sehingga artinya hipotesis ketiga yang memprediksi pergantian kantor akuntan publik berpengaruh terhadap reaksi investor pada penelitian ini diterima. Artinya semakin tinggi switching sebuah perusahaan maka akan semakin meningkatkan AR perusahaan yang bersangkutan.

Berdasarkan pada hasil pengujian hipotesis diketahui bahwa nilai signifikansi $t$ untuk variabel Reputasi KAPlebih besar daripada 0,05 sehingga artinya hipotesis keempat yang memprediksi perubahan reputasi kantor akuntan publik berpengaruh terhadap reaksi investor pada penelitian ini ditolak. Jadi Reputasi KAP tidak berpengaruh signifikan terhadap AR (reaksi investor).

Berdasarkan pada hasil pengujian hipotesis diketahui nilai signifikansi $t$ untuk variabel UE lebih besar daripada 0,05 sehingga artinya hipotesis kelima yang memprediksi Informasi laba berpengaruh terhadap reaksi investor pada penelitian ini ditolak. Jadi UE tidak berpengaruh signifikan terhadap AR (reaksi investor). Informasi laba merupakan hal yang berhubungan dengan laba atau profit yang diperoleh perusahaan.

\section{SIMPULAN}

\section{Kesimpulan}

Berdasarkan pada hasil analisis dan pembahasan pada bagian sebelumnya maka kesimpulannya adalah:

1. Timelinessberpengaruh signifikan terhadap reaksi investor. Hal ini dapat dilihat dari nilai signifikansi t dibawah 0.05 sehingga hipotesis diterima. Artinya semakin tinggi timeliness akan berdampak pada reaksi investor karena berarti ini adalah berita baik bagi investor. Hasil penelitian ini mendukung penelitian Sultony (2013).

2. Opinitidak berpengaruh signifikan terhadap reaksi investor. Hal ini dapat dilihat dari nilai signifikansi t diatas 0.05 sehingga hipotesis ditolak. Artinya opini audit baik ataupun buruk tidak berpengaruh terhadap reaksi investor. Hasil penelitian ini mendukung penelitian Fernandes (2012).

3. Switching berpengaruh signifikan terhadap reaksi investor. Hal ini dapat dilihat dari nilai signifikansi t dibawah 0.05 sehingga hipotesis diterima. Artinya perpindahan auditor akan berpengaruh terhadap reaksi investor karena ini merupakan berita baik maupun buruk bagi investor. Hasil penelitian ini mendukung penelitian Firiana (2014).

4. Perubahan reputasi KAPtidak berpengaruh signifikan terhadap reaksi investor. Hal ini dapat dilihat dari nilai signifikansi t diatas 0.05 sehingga hipotesis ditolak. Artinya perusahaan diaudit oleh KAP Big Four maupun Non Big Four tidak berdampak pada reaksi investor. Hasil penelitian ini mendukung penelitian yang dilakukan Diaz (2009).

5. UE tidak berpengaruh signifikan terhadap reaksi investor. Hal ini dapat dilihat dari nilai signifikansi t diatas 0.05 sehingga hipotesis ditolak. Artinya UE tinggi maupun rendah tidak berdampak pada reaksi investor. Hasil penelitian ini mendukung penelitian Sari (2011).

\section{Saran}

Sedangkan saran yang dapat dikemukakan pada penelitian ini adalah sebagai berikut:

1. Sebaiknya para investor dalam menanamkan investasinya pada sebuah perusahaan memperhatikan berbagai faktor yang mempengaruhi AR yaitu Timeliness dan 
auditor Switching karena berdasarkan pada penelitian ini variabel tersebut berpengaruh terhadap abnormal return.

2. Pada penelitian berikutnya dapat ditambahkan variabel lain yang mempengaruhi AR, seperti rasio likuiditas, ROA, ROE, kurs dan sebagainya.

\section{DAFTAR PUSTAKA}

Agustina L. dan K. Ferlysia. 2012. Pengaruh Informasi LabaAkuntansi Terhadap Abnormal Return pada Perusahaan yang Tergabung Dalam Indeks LQ45. Jurnal Akuntansi 4(2): 135-152.

Butar Butar, S. 2007. Modul Statistik dan Aplikasi SPSS. Semarang: Fakultas Ekonomi Unika Soegijapranata.

Butar Butar, S. 2016. Merger Auditor dan Kualitas Audit: Bukti Empiris Dari Bursa Efek Indonesia. Jurnal Ekonomi dan Bisnis 17 (2): 107-128

Cokro, S.H. 2014. Analisis Pergantian Kantor Akuntan Publik dan Ketepatan Waktu Dalam Pelaporan Laporan Keuangan Terhadap Reaksi Pasar. Skripsi. Semarang: Undip.

Diaz, M. 2009. Analisis Reaksi Pasar Terhadap Pengumuman Pergantian Kantor Akuntan Publik. Jurnal Simposium NasionalAkuntansi XIII.

Diputra R. S. dan A. Y. Devi. 2013. Pengaruh Ketepatan Pelaporan Laporan Keuangan, Opini Audit, Pergantian Kantor Akuntan Publik, Dan Reputasi Kantor Akuntan Publik Terhadap Reaksi Investor. Jurnal Bina Ekonomi. 18 (2): 39-59.

Fernandes, Y. dan Y.K.Susanto. 2012. Reaksi Pasar Terhadap Karakteristik Perusahaan dan Kantor Akuntan Publik. Jurnal Bisnis dan Akuntansi 14 (1).

Fitriadi S. D. 2011. Analisis Reaksi Pasar Terhadap Pergantian Kantor Akuntan Publik dan Opini Audit (Studi Pada Perusahaan LQ 45 Tahun 2007-2009).

Hartono, J. M.2008. Teori Portofolio dan Analisis Investasi. Yogyakarta: Kanisius.

Hartono, J. M. 2004. Metode Penelitian dan Bisnis. Edisi 1. BPFE : Yogjakarta.

Keputusan Ketua Badan Pengawas Pasar Modal dan Lembaga Keuangan Nomor: KEP346/BL/2011.

Nezky M. 2008. Pengaruh Krisis Ekonomi Amerika SerikatterhadapBursa Saham dan Perdagangan Indonesia. Buletin Ekonomi Moneter dan Perbankan : 90-103. 
Peraturan Menteri Keuangan Republik Indonesia. 2008. Tentang Jasa Akuntan Publik. Nomor: 17/PMK.01/2008, Jakarta.

Riyatno. 2007. Public Accounting Firm Size Effect on Earnings Response Coefficients. Journal of Financial and Business, 5(2).

Sari, M. 2011. Anomali Reaksi Investor Terhadap Pungumuman Laba Good News dan Laba Bad News. Skripsi. Universitas Andalas : Padang.

Wicaksono, A. dan S. Rahaja. 2012. Adakah Kandungan Informasi Laporan Audit WTP Dengan Paragraf Penjelas dan Laporan Audit WDP. Jurnal Dinamika

Yanti, F. 201. Pengujian Abnormal Return Saham Sebelum dan Sesudah Peluncuran Indeks Saham Syariah Indonesia (ISSI). Jurnal Manajemen, Volume 01, Nomor 01. Hal 1-17. 